\title{
The Correlation between Serum Cortisol Levels with Stretch Marks in Gymnastic Male
}

\author{
Rezky Darmawan Hatta ${ }^{1 *(D)}$, Imam Budi Putra ${ }^{2}$ (D) Nelva Karmila Jusuf ${ }^{2}$ (D) \\ ${ }^{1}$ Department of Dermatology and Venereology, Postgraduate Master of Clinical Medicine, Faculty of Medicine, Universitas \\ Sumatera Utara, Universitas Sumatera Utara Hospital, Medan, Indonesia; ${ }^{2}$ Department of Dermatology and Venereology, \\ Faculty of Medicine, Universitas Sumatera Utara, Universitas Sumatera Utara Hospital, Medan, Indonesia
}

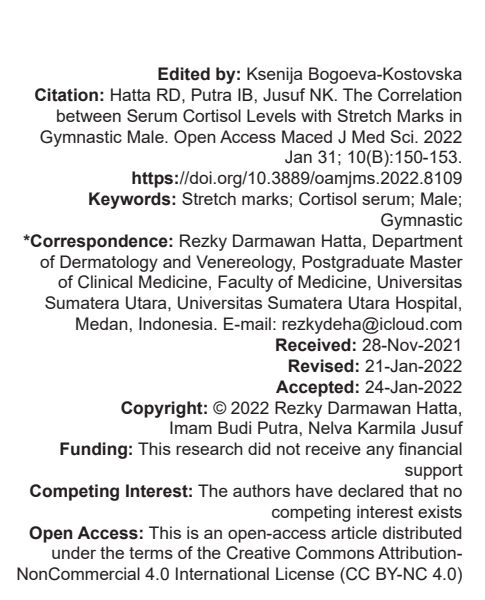

Abstract

BACKGROUND: Stretch marks are skin scar tissue that appears in the form of purplish linear atrophy, erythematous or hypopigmented which is often caused by excessive stretching of the skin. Increased cortisol levels can cause an increase in collagen degradation which results in disruption of the extracellular matrix in the dermis, resulting in stretch marks. Physical stress can trigger activation of the hypothalamic-pituitary-adrenal axis, which will induce activation of stress hormones, including cortisol in the adrenal cortex.

AIM: The objective of the study is to determine the correlation between serum cortisol levels and stretch marks in male at a gymnastics training site.

SUBJECTS AND METHODS: Observational analytic study with a cross-sectional approach to 50 stretch marks subjects.

RESULTS: Serum cortisol levels of subjects with stretch marks averaged $9.72 \mathrm{~g} / \mathrm{dL}$ with the lowest level of $4.45 \mathrm{~g} / \mathrm{dL}$ and the highest level of $49.25 \mathrm{~g} / \mathrm{dL}(\mathrm{p}<0.001)$. The highest age with stretch marks was $26-30$ years $18(36 \%)$ subjects and the lowest age was aged $36-40$ years $5(10 \%)$ subjects. The majority of stretch marks are located in the axillary region (30.9\%), brachii (23.6\%), and abdomen (18.4\%). The average cortisol level in subjects with aerobic exercise was $6.52 \mathrm{~g} / \mathrm{dL}$, muscle training $11.18 \mathrm{~g} / \mathrm{dL}$, mixed aerobic and muscle training $7.5 \mathrm{~g} / \mathrm{dL}$. The highest average cortisol levels were at exercise duration of $31-60 \mathrm{~min}$ of $12.88 \mathrm{~g} / \mathrm{dL}, 61-90 \mathrm{~min}$ of $6.63 \mathrm{~g} / \mathrm{dL}$, and $91-120 \mathrm{~min}$ of $6.2 \mathrm{~g} / \mathrm{dL}$. The highest frequency of exercise in a week was 3-4 times as many as 30 subjects $(60 \%)$ with an average serum cortisol level of $11.1879 \mathrm{~g} / \mathrm{dL}$.

CONCLUSION: There is a significant correlation between serum cortisol levels and stretch marks in male at gymnastics training.

\section{Introduction}

Striae distensea or stretch marks are a type of skin scar tissue that appears in the form of purplish linear atrophy, erythematous or hypopigmented which is often caused by excessive stretching of the skin [1], [2]. Stretch marks are clinically in the form of atrophic scars that are initially reddish or purplish in color and overtime it tends to fade gradually and turn white [3]. Stretch marks are not a dangerous disease, but they can cause cosmetic and psychological problems for sufferers [4].

The hypothesis of the pathogenesis of stretch marks is divided based on the underlying etiological theory, namely, genetic factors, pathological factors, hormonal factors, and mechanical factors [5]. Increased cortisol levels can cause an increase in collagen degradation which results in disruption of the extracellular matrix in the dermis, this can result in stretch marks [6]. The mechanism for the formation of stretch marks caused by the action of steroid hormones and glucocorticoid hormones appears to be an imbalance of the dermal connective tissue and/or dermal matrix rather than mechanical stress [5]. High levels of steroid hormones and glucocorticoid hormones have a catabolic effect on fibroblast activity and reduce collagen deposition. in the dermal matrix substance [7]. The pathogenesis of stretch marks, according to Shuster, is caused by cross-linking of immature collagen in the dermis, resulting in intradermal rupture causing stretch marks. It has been found that in stretch marks there is a deposition of collagen bundles and the formation of scar tissue which has implications for the formation of stretch marks [7].

Physical stress can trigger the activation of a number of physiological responses, including the endocrine, nervous, and immune systems. The physiological response to stress involves activation of the hypothalamic-pituitary-adrenal (HPA) axis, and the medullary sympathetic-adrenal axis, both of which interact with immune function. Activation of the HPA axis will induce the activation of key stress hormones, including corticotropin-releasing hormone 
in the hypothalamus, adrenocorticotropic hormone in the anterior pituitary, and cortisol in the adrenal cortex, which in turn will disrupt the balance of cellular immunity mediated by T-helper (Th) 1 and humoral immunity is mediated by Th2 [8], [9]. This study is conducted to find the correlation serum cortisol levels and stretchmark in gymnastic male.

\section{Methods}

This study was an analytic observational study with a cross-sectional design consisting of 50 stretch marks subjects and 50 controls with age $\geq 18$ years old that normal weight and doing exercise in gymnastics. Each subject had signed the informed consent. The exclusion criteria were subjects with cushing's syndrome or Marfan's syndrome, have a history of obesity, using oral or topical steroids and topical tretinoin for more than 6 months before the first appearance of stretch marks, taking drugs that affect cortisol levels such as antidepressants, antipsychotics, and anti-anxiety drugs in the past 30 days.

Ethical permission is given by the Health Research Ethics Committee, Faculty of Medicine, Sumatera Utara University, and Universitas Sumatera Utara Hospital Medan. History taking and clinical examination were conducted, and measurement of serum cortisol levels. The results were analyzed in descriptive analysis and MannWhitney test to determine the correlation between serum cortisol levels with stretch marks in gymnastic male, with $p<0.05$ was considered significant.

\section{Results}

In this study, the majority of subjects were aged 26-30 years with 18 (36\%) subjects, and the majority control group were aged of 18-25 years as many as $19(38 \%)$ subjects. The demographic characteristics of the subjects were shown in Table 1. From 50 subjects with stretch marks, we found 152 stretch marks distributed in several predilections, and most were found in the axilla (30.9\%) and a brachii $(23,6 \%)$ (Table 2).

In the stretch marks, group cortisol levels were $9.72 \mathrm{~g} / \mathrm{dL}$ with the lowest level of $4.45 \mathrm{~g} / \mathrm{dL}$ and the

Table 1: Distribution of subjects and controls based on age

\begin{tabular}{lllll}
\hline Age (year) & Subject & $\%$ & Control & $\%$ \\
\hline $18-25$ & 13 & 26 & 19 & 38 \\
$26-30$ & 18 & 36 & 14 & 28 \\
$31-35$ & 14 & 28 & 14 & 28 \\
$36-40$ & 5 & 5 & 3 & 6 \\
Total & 50 & 100 & 50 & 100 \\
\hline
\end{tabular}

Table 2: Distribution of subjects by location of stretch marks

\begin{tabular}{lll}
\hline Location & $\mathrm{n}$ & $\%$ \\
\hline Axsilla & 47 & 30,9 \\
Brachii & 36 & 23,6 \\
Abdomen & 28 & 18,4 \\
Lumbosacral & 16 & 10,5 \\
Gluteus & 15 & 9,8 \\
Femur & 8 & 5,2 \\
Poplitea & 2 & 1,3 \\
Total & 152 & 100 \\
\hline
\end{tabular}

highest level of $49.25 \mathrm{~g} / \mathrm{dL}$. Meanwhile, in the group of subjects who did not have stretch marks, the cortisol value was much lower with an average of $3.83 \mathrm{~g} / \mathrm{dL}$ with the lowest level of $1.84 \mathrm{~g} / \mathrm{dL}$ and the highest level of $5.39 \mathrm{~g} / \mathrm{dL}$ as shown in Table 3.

Table 3: Relationship of serum cortisol levels with stretch marks

\begin{tabular}{llll}
\hline Cortisol, $\mu \mathrm{g} / \mathrm{dL}$ & Stretch marks $(+) \mathrm{n}=50$ & Stretch marks $(-) \mathrm{n}=50$ & $\mathrm{p}$ \\
\hline Mean & $9.72(9.44)$ & $3.83(0.89)$ & $<0.001^{*}$ \\
Median & $6.37(4.45-49.25)$ & $3.85(1.84-5.39)$ & \\
(Min-Max) & & & \\
\hline
\end{tabular}

In Table 4 shows the results of the type of exercise and serum cortisol levels, the average cortisol level in the 11 subjects with aerobic exercise was $6.52 \mathrm{~g} /$ $\mathrm{dL}$, the average cortisol level in the 11 subjects with exercise muscle training was $11.18 \mathrm{~g} / \mathrm{dL}$, the average cortisol level in the 11 subjects with aerobic exercise and muscle training was $7.5 \mathrm{~g} / \mathrm{dL}$.

Table 4: Distribution of exercise types with serum cortisol levels

\begin{tabular}{lll}
\hline Exercise type & $\mathrm{n}$ & $\mu \mathrm{g} / \mathrm{dL}$ \\
\hline Aerobic & 11 & \\
Mean (SD) & & $6.52(1.48)$ \\
Median (Min-Max) & 33 & $6.44(4.75-8.41)$ \\
Muscle training & & $11.18(11.26)$ \\
Mean (SD) & & $6.51(4.45-49.25)$ \\
Median (Min-Max) & 6 & $7.5(3.87)$ \\
Aerobic dan muscle training & & $5.81(5.02-14.96)$ \\
Mean (SD) & & \\
Median (Min-Max) &
\end{tabular}

In Table 5 show that the 50 most subjects did exercise with a duration of $31-60 \mathrm{~min}$, as much as 23 people (48\%) with a serum cortisol level of $12.8788 \mathrm{~g} / \mathrm{dL}$, followed by a duration of $61-90 \mathrm{~min}$, as much as 17 people (34\%) with a serum cortisol level of $6.6322 \mathrm{~g} / \mathrm{dL}$. Distribution of subjects based on the frequency of exercise in a week and serum cortisol levels in 50 subjects who have stretch marks shown in Table 6, it can be seen that 50 subjects did exercise with a frequency of 1-2 times, 7 people (14\%) with a serum cortisol level of $8.1737 \mathrm{~g} / \mathrm{dL}$, followed by a frequency of 3-4 times, 30 people (60\%) with the serum cortisol level was $11.1879 \mathrm{~g} / \mathrm{dL}$ and with a frequency of 5-7 times, 13 people (26\%) with a serum cortisol level of $7.1460 \mathrm{~g} / \mathrm{dL}$.

Table 5: Distribution of subjects based on the duration of exercise

\begin{tabular}{llll}
\hline Duration of exercise $(\mathrm{min})$ & $\mathrm{n}$ & $\%$ & $\mu \mathrm{g} / \mathrm{dL}$ \\
\hline $1-30$ & 2 & 4 & 6,1593 \\
$31-60$ & 23 & 48 & 12,8788 \\
$61-90$ & 17 & 34 & 6,6322 \\
$91-120$ & 4 & 8 & 6,2064 \\
$>120$ & 4 & 6 & 6,3625 \\
Total & 50 & 100 & \\
\hline
\end{tabular}


Table 6: Distribution of subjects based on the frequency of exercise in a week

\begin{tabular}{llll}
\hline Frequency of exercise & $\mathrm{n}$ & $\%$ & $\mu \mathrm{g} / \mathrm{dL}$ \\
\hline $1-2$ times & 7 & 14 & 8,1737 \\
$3-4$ times & 30 & 60 & 11,1879 \\
$5-7$ times & 13 & 26 & 7,1460 \\
Total & 50 & 100 & \\
\hline
\end{tabular}

We then analyzed them with the MannWhitney test and found that there was a significant correlation between stretch marks and cortisol serum levels $(p<0.001)$.

\section{Discussion}

Stretch marks are a very common condition in most age groups in the form of linear atrophic scars that form in areas of skin damage and are produced by stretching 20 . In the early stages, stretch marks appear as pink or purple lesions without any compression, but gradually stretch marks become paler, compressed, and wrinkled [10], [11]. Stretch marks occur in pregnancy $(43 \%$ to $88 \%)$, puberty $(6 \%$ to $86 \%)$, and obesity (43\%). $570 \%$ of adolescent girls, and $40 \%$ of boys (who are active in sports) have stretch marks [12].

Table 1 showed that the majority of subjects were aged $26-30$ years with $18(36 \%)$ subjects and the majority control group were aged 18-25 years as many as $19(38 \%)$ subjects. This study is consistent with the study by Dharmesti et al. in Denpasar, Indonesia conducted on 28 males, the mean age was 20.6 years. 73 Trojan et al. in Lodz, Poland conducted a study on 80 people with stretch marks and found the average age was $23.9 \pm 2.05$ years [13]

We found 152 stretch marks distributed in several predilections, and most were found in the axilla (30.9\%) and a brachii (23.6\%). In line with the research conducted by Dharmesti et al. in Denpasar, Indonesia which was conducted on 28 males, it was found that striae distensae developed the most in the forearm area $(29.6 \%)$, followed by the abdominal area $(15.5 \%)$, then gluteus and lumbosacral areas with the same percentage (9.9\%). 73 In this study, the most common locations for stretch marks in the axillary and brachial regions were due to the dominant movement factor in the gymnastics using upper extremity movements [13].

Based on Table 3, In the stretch marks group, cortisol levels were $9.72 \mathrm{~g} / \mathrm{dL}$, meanwhile, in the group of subjects who did not have stretch marks, the cortisol value was much lower with an average of $3.83 \mathrm{~g} / \mathrm{dL}$. This study is consistent with Simkim and Arce studied 24-h urinary excretion of 17-ketosteroids and 17-ketogenic steroids in obese patients. Although the mean excretion of all obese patients $(15.8 \mathrm{mg})$ was significantly higher, compared with non-obese patients, excretion was higher in obese patients who had skin striae $(20.4 \mathrm{mg})$. Approximately $78 \%$ of obese patients with striae showed an increase in 17-ketosteroids, but this result was not statistically significant [14].

In this study, from 50 subjects with stretch marks, we found the type of exercise and serum cortisol levels, the average cortisol level in the 11 subjects with aerobic exercise was $6.52 \mathrm{~g} / \mathrm{dL}$, the average cortisol level in the 11 subjects with exercise muscle training was $11.18 \mathrm{~g} / \mathrm{dL}$, the average cortisol level in the 11 subjects with aerobic exercise and muscle training was $7.5 \mathrm{~g} / \mathrm{dL}$. Cortisol levels that increase during exercise are caused by changes in homeostasis with an increase in energy requirements that are higher than the control group. This is in accordance with the study of Howlett et al., which showed a higher increase in cortisol in moderate exercise. The increase occurs due to an increase in the need for blood glucose through the gluconeogenesis pathway [15].

In Table 5 show that the 50 most subjects did exercise with the highest serum cortisol level of $12.8788 \mathrm{~g} / \mathrm{dL}$ in the duration of 31-60 $\mathrm{min}$, as much as 23 people (48\%). In Table 6 , it can be seen that 50 subjects did exercise with a frequency of 1-2 times, 7 people $(14 \%)$ with a serum cortisol level of $8.1737 \mathrm{~g} / \mathrm{dL}$, followed by a frequency of 3-4 times, 30 people (60\%) with the serum cortisol level was $11.1879 \mathrm{~g} / \mathrm{dL}$ and with a frequency of 5-7 times, 13 people (26\%) with a serum cortisol level of $7.1460 \mathrm{~g} / \mathrm{dL}$. Seller et al. conducted a biological study to see a significant glucocorticoid response during exercise in experimental animals and found that in short-term exercise blood cortisol levels increased if the intensity of exercise was above a certain threshold [16].

\section{Conclusion}

There is a correlation between serum cortisol levels with stretch marks in gymnastic male.

\section{Acknowledgments}

We want to express gratitude to the Head of the Cosmetic Division Department of Dermatology and Venereology of Faculty of Medicine Universitas Sumatera Utara and Universitas Sumatera Utara Hospital.

\section{Author Contribution}

All authors have contributed to this research process, including preparation, data gathering, analysis, drafting, and approval to publish this manuscript. 


\section{References}

1. Cooper MS, Stewart PL. Corticosteroid insuficien-cy in acutely ill patients. N Engl J Med. 2003;348:727-34. https://doi. org/10.1056/NEJMra020529

PMid:12594318

2. Bertagna X. Effects of chronic ACTH excess on human adrenal cortex. Front Endocrinol (Lausanne). 2017;8:43. https://doi. org/10.3389/fendo.2017.00043

PMid:28337175

3. Coimbra S, Oliveira H, Figueiredo A, Rocha-Pereira $P$, Santos-Silva A. Psoriasis: Epidemiology, clinical and histological features, triggering factors, assessment of severity and psychosocial aspects. In: O'Daly J, editor. Psoriasis-a Systemic Disease. Croatia: InTech; 2012. p. 69-82.

4. Arck PC, Slominski A, Theoharis TC, Peters EM, Paus R. Neuroimmunology of stress: skin takes center stage. J Invest Dermatol. 2006;126(8):1697-704. https://doi.org/10.1038/ sj.jid. 5700104 PMid:16845409

5. del Rey A, Chrousos G, Besedovsky H. Neurolmmune Biology, the Hypothalamus-Pituitary-adrenal Axis. Amsterdam: Elsevier; 2008.

6. Gomes R, Rosa G, José R, Henrique E. Cortisol and Physical Exercise; 2012. Available from: https://www.researchgate.net/ publication/228160384 [Last accessed on 2021 May 25].

7. Ghaderi M, Azarbayjani M, Atashak S, Shamsi M, Saei S, Sharafi $\mathrm{H}$. The effect of maximal progressive exercise on serum cortisol and immunoglobulin a responses in young elite athletes. Ann Biol Res. 2011;2(6):456-63.

8. Cho S, Park E, Lee D, Li K, Chung J. Clinical features and risk factors for stretch marks distense in korean adolescents. J Eur Acad Dermatol Venereol. 2016;20(9):1108-13. https://doi. org/10.1111/J.1468-3083.2006.01747.X

PMid:16987267

9. Yousef SE, El-Khateeb EA, Ali DG. Striae distense: Immunohistochemical assessment of hormone receptors in multigravida and nulligravida. J Cosmet Dermatol. 2017;16(2):279-86. https://doi.org/10.1111/jocd.12337 PMid:28374517

10. Catherine J, Maarie P. Atrophies of Connective Tissue, in Dermatology. New York: Elsevier; 2018. p. 1723-32.

11. Rongioletti $F$, Romanelli P. Dermal infiltrates. In: Kerdel FA, Jimenez A, editor. In Dermatology Just The Facts. New York: Mcgraw-Hill; 2003. p. 266.

12. Alaiti S. Striae Distensae. India: eMedicine; 2017. p. 1-9.

13. Kasielska-Trojan A. Do body build and composition influence striae distense occurrence and visibility? J Cosmet Dermatol. 2017;17(6):1165-9. https://doi.org/10.1111/Jocd.12455 PMid:29105985

14. Simkin B, Arce R. Steroid excretion in obese patient with colored abdominal striae. N Engl J Med 1962;266:1031-5. https://doi. org/10.1056/NEJM196205172662004

PMid:13913027

15. Howlett K, Galbo $\mathrm{H}$, Lorentsen J, Bergeron $\mathrm{R}$ Zimmerman-Belsing T,BulowJ, etal.Effectofadrenalineonglucose kinetics during exercise in adrenaletomised humans. J Physiol. 519(3):911-21. https://doi.org/10.1111/j.1469-7793.1999.0911n.x PMid: 10457100

16. Viru A. Plasma hormones and physical exercise. Int J Sports Med. 1992;13(3):201-9. https://doi.org/10.1055/s-2007-1021254 PMid:1601554 